\title{
Regulation of inhibin production by bovine ovarian cells in vitro
}

\author{
K. M. Henderson and P. Franchimont* \\ Department of Biochemistry, University of Western Australia, Nedlands, Western Australia \\ 6009 and ${ }^{*}$ Laboratoire de Radioimmunologie, Institut de Pathologie, B23 Université de \\ Liège, Belgium
}

\begin{abstract}
Summary. The regulation of ovarian inhibin production was investigated using a rat pituitary cell culture system as a bioassay for inhibin activity. Bovine follicular granulosa cells produced inhibin in vitro provided that the culture medium contained serum. The stimulatory factor(s) present in serum is unlikely to be gonadotrophins, because bovine $\mathrm{LH}$ and/or FSH failed to stimulate inhibin production when added to medium devoid of serum. Luteinization of granulosa cells in culture was accompanied by a reduction in their inhibin production and an inverse relationship existed between inhibin and progesterone production by granulosa cells. Bovine corpus luteum cells in culture failed to produce detectable amounts of inhibin.

Androgens stimulated granulosa cell inhibin production with testosterone and $5 \alpha$-dihydrotestosterone being more potent than androstenedione. The androgens did not stimulate inhibin production by luteal cells. Progesterone inhibited granulosa cell inhibin production but oestrogens had no effect. Measurement of steroids and inhibin in fluid from individual follicles indicated that as follicle size increased, concentrations of oestradiol-17 $\beta$ increased, testosterone and inhibin decreased and progesterone remained unchanged. The stimulatory effect of testosterone on inhibin production in vitro together with the parallel changes in follicular fluid concentrations of testosterone and inhibin suggest that ovarian inhibin production in vivo may be controlled, at least in part, through androgens modifying granulosa cell inhibin production. The inhibitory effect of progesterone on granulosa cell inhibin production may be more important in regulating ovarian inhibin production at the time of granulosa cell luteinization and CL formation. The stimulatory effect of androgens on granulosa cell inhibin production might also be a means by which androgens promote follicular atresia.
\end{abstract}

\section{Introduction}

The ovary, like the testis, may produce a non-steroidal compound, inhibin, which is capable of inhibiting pituitary FSH secretion (Franchimont et al., 1979b). Steroid free bovine (de Jong, Welschen, Hermans, Smith \& van der Molen, 1978), equine (Miller, Wesson \& Ginther, 1979), human (Chappel, Holt \& Spies, 1980), monkey (Channing, Anderson \& Hodgen, 1980) and porcine (de Paolo, Wise, Anderson, Barraclough \& Channing, 1979b; Schander, Anderson, Barraclough \& Channing, 1980) follicular fluid selectively reduce FSH levels in vivo and/or selectively inhibit FSH production by anterior pituitary cells in vitro. Erickson \& Hsueh (1978) indicated that granulosa cells are the probable source of this follicular inhibin, while studies of the rat (de Paolo, Shander, Wise, Barraclough \& Channing, 1979a) and monkey (Channing et 
al., 1980) have shown that inhibin is secreted into the ovarian vein, thus strengthening the concept that ovarian inhibin may be physiologically important in the regulation of FSH secretion. Inhibin activity in follicular fluid is related to follicle size (Welschen, Hermans, Dullart \& de Jong, 1977) and ovarian inhibin production changes throughout the oestrous/menstrual cycle (de Paolo et al., 1979a; Chappel et al., 1980). However, there is little information about the regulation of ovarian inhibin production. The aim of the present study was to investigate (a) the regulation of inhibin production by bovine ovarian cells in vitro and (b) the relationship between the inhibin concentration in individual bovine follicles to their hormonal environment.

\section{Materials and Methods}

\section{Reagents}

Purified bovine gonadotrophins were provided by Bioproducts, Peptide Department (UCB, Brussels, Belgium). The bovine FSH had a potency 60 times that of NIH-FSH-B 1 (Steelman-Pohley assay) and LH contamination of $<3 \%$ (RIA) or $<0.45 \%$ (RRA). The bovine LH had a biological activity of 2.3 i.u./mg (Parlow assay) with FSH contamination of $<0.05 \%$ (by bioassay with NIH-FSH-S9 as standard). Steroids were obtained from Sigma (London) Chemical Co. Ltd, Poole, Dorset, U.K.

\section{Bovine follicular fluid}

Ovaries were obtained from healthy adult cows within $1 \mathrm{~h}$ of their slaughter at a local abattoir. Follicular fluid was aspirated from all visible antral follicles and that from follicles containing $\leqslant 0 \cdot 1 \mathrm{ml}$ fluid was pooled for follicles from the same ovary or each pair of ovaries. Aliquots taken for inhibin determination were freeze-dried while the remaining follicular fluid was stored frozen for subsequent steroid determination.

\section{Ovarian cell cultures}

Granulosa cells. Granulosa cells harvested and pooled from antral follicles containing $\geqslant 0.3$ $\mathrm{ml}$ follicular fluid were cultured as described previously (Henderson \& Moon, 1979). Briefly, a minimum of $10^{5}$ 'live' cells were cultured in multi-welled tissue culture Petri dishes (Sterilin, Middlesex, U.K.) at $37^{\circ} \mathrm{C}$ in $1 \mathrm{ml}$ culture medium consisting of $10 \%$ donor calf serum and $90 \%$ Eagle's Minimum Essential Medium (Modified) with Earle's Salts (Eagle, 1959) and supplemented with Hepes buffer $(20 \mathrm{mM})$, glutamine $(2 \mathrm{~mm})$, penicillin $(50$ units $/ \mathrm{ml})$, streptomycin $(50 \mu \mathrm{g} / \mathrm{ml})$, amphotericin B $(0.625 \mu \mathrm{g} / \mathrm{ml})$ and non-essential amino acids (Eagle, 1959) (all reagents obtained from Flow Laboratories, Irvine, Scotland). The gas phase was air. The medium was replaced at selected times and aliquots taken and freeze-dried for subsequent inhibin determination while the remainder was stored frozen until assayed for steroids. At the end of the culture period the cells were washed thoroughly with culture medium devoid of calf serum and assayed for protein by the method of Lowry, Rosebrough, Farr \& Randall (1951) as modified by Patterson (1979). In some preliminary studies, granulosa cells were cultured in the above medium devoid of calf serum. Steroids (see bleow) were added to the culture media in ethanol, with control cultures receiving ethanol alone. The ethanol concentration in the culture media never exceeded $1 \%$.

Luteal cells. Dispersed cells were obtained as described previously (Henderson \& Moon, 1979). Briefly, corpora lutea were freed of adherent connective tissue, cut into small pieces approximately $2 \mathrm{~mm}$ in diameter and washed in Hanks' Balanced Salt Solution (Flow Laboratories) devoid of magnesium and calcium but supplemented with Hepes, glutamine and antibiotics as described above (HBS-HGA). Tissue dissociation was achieved by stirring at 
$37^{\circ} \mathrm{C}$ in $\mathrm{HBS}-\mathrm{HGA}$ containing $0.2 \%$ collagenase (Type II, Sigma), the released cells being collected after incubation for 20 and $40 \mathrm{~min}$. Final dispersal of remaining tissue fragments was achieved by drawing through a syringe tip and a series of needles (18-22 gauge). The freed cells were pooled, filtered through sterile gauze, washed 4 times and their viability determined using nigrosin dye. The procedure for the culture of the luteal cells was exactly as described above for the granulosa cells.

\section{Inhibin assay}

The assay of inhibin activity was based on the selective inhibition of basal and LH-RH-induced FSH secretion by cultured anterior pituitary cells as described by Franchimont, Demoulin, Verstraelen-Proyard, Hazee-Hageistein \& Tunbridge (1979a). Dispersed anterior pituitary cells from adult male Wistar rats were obtained by enzymic digestion using the technique described by Hopkins \& Farquhar (1973). The dispersed cells $\left(1 \times 10^{6}\right)$ were cultured at $37^{\circ} \mathrm{C}$ on Petri dishes (Falcon Plastics) in $3 \mathrm{ml}$ Dulbecco's Modified Eagles Medium (Dulbecco \& Freeman, 1959) supplemented with 5\% horse serum, $2.5 \%$ fetal calf serum, $1 \%$ glutamine and $1 \%$ non-essential amino acids (Flow Laboratories). The gas phase was a water-saturated atmosphere of $95 \%$ air and $5 \% \mathrm{CO}_{2}$. After 3 days of culture, the medium was discarded and replaced with $1.6 \mathrm{ml}$ of medium containing the test material or a reference standard preparation of inhibin. Incubation was continued for a further 3 days and then the medium was removed and stored frozen until assayed for gonadotrophins. The culture plates were washed and incubation was continued with $1.6 \mathrm{ml}$ medium containing standards or test material and $\mathrm{LH}-\mathrm{RH}$ at a final concentration of $10^{-8} \mathrm{M}$. After incubation for $6 \mathrm{~h}$ the medium was removed and stored frozen until assayed for gonadotrophins.

The freeze-dried aliquots of follicular fluid and cell culture medium taken for inhibin assay were reconstituted with distilled water. Steroids were removed by mixing for $16 \mathrm{~h}$ at $4^{\circ} \mathrm{C}$ with activated charcoal (Norit A, $1 \%$ ) pretreated with dextran $(0.1 \%)$ followed by centrifugation at $3000 \mathrm{~g}$. The supernatants were filter-sterilized by passing through a $0.45 \mu \mathrm{m}$ cellulose millipore filter before use. Such dextran-charcoal treatment removed $>99.8 \%$ of exogenous steroids added to culture medium while endogenous steroids present in follicular fluid were undetectable after this treatment. In the pituitary cell culture medium, the concentration of follicular fluid ranged from 0.5 to $5 \%(\mathrm{v} / \mathrm{v})$ and that of granulosa or luteal cell culture medium ranged from 3 to $60 \%(\mathrm{v} / \mathrm{v})$. Culture medium with and without added steroids incubated in the absence of granulosa or luteal cells served as control medium for adding to the pituitary cell culture medium. The standard reference preparation of inhibin, kindly supplied by Professor B. Hudson (Howard Florey Institute of Experimental Physiology and Medicine, Melbourne, Australia) was derived from ovine testicular lymph (OTLP6) and has been given an arbitrary potency of 1 $\mathrm{U} / \mathrm{mg}$ (Eddie, Baker, Higginson \& Hudson, 1979). This inhibin standard was added to the pituitary cell cultures at doses of 250 to $2000 \mu \mathrm{g} / \mathrm{ml}$. Each standard and aliquot of test material was added to 5 replicate pituitary cell cultures. Inhibin activity in follicular fluid or culture media was expressed relative to the activity of the OTLP6 standard.

\section{Radioimmunoassays}

The gonadotrophin concentrations in media from the pituitary cell cultures were measured in duplicate by double-antibody methods using NIAMDD rat pituitary gonadotrophin reagents supplied by the pituitary agency of NIH. The concentrations are expressed in terms of NIAMDD rat-FSH-RP 1 for FSH and rat-LH-RP1 for LH. The sensitivities of the assays were 5 $\mathrm{ng} \mathrm{FSH} / \mathrm{ml}$ and $10 \mathrm{ng} \mathrm{LH} / \mathrm{ml}$. The inter- and intra-assay coefficients of variation were 3 and $8 \%$ for the FSH assay and 5 and $12 \%$ for the LH assay respectively.

Steroid concentrations in follicular fluid and granulosa and luteal cell culture media were 
determined using specific radioimmunoassays described previously (Neal, Baker, McNatty \& Scaramuzzi, 1975; Van Look, Hunter, Corker \& Baird, 1977; Corker \& Davidson, 1978). The limits of sensitivity of the assays (per tube) were $25 \mathrm{pg}$ for progesterone, $5 \mathrm{pg}$ for oestradiol-17 $\beta$ and $10 \mathrm{pg}$ for testosterone. The intra- and inter-assay coefficients of variation of all the steroid assays were each $<10 \%$ and $<16 \%$ respectively.

\section{Statistics}

Unless otherwise stated, data were subjected to analyses by paired or unpaired Student's $t$ test.

\section{Results}

Specificity and validity of inhibin assay

As shown in Text-fig. 1, each preparation caused a dose-dependent inhibition of FSH secretion in basal and LH-RH stimulated conditions. The significance of regression (Finney's $Q$ ) was always higher than 0.01 . Variations in the slopes were not significant $\left(\mathrm{G}^{2}, P>0.05\right.$; Finney, 1964) and the curves were therefore considered to run parallel. LH secretion was reduced only in LH-RH treated cultures and only by much higher amounts of the test substances than those required to impair FSH secretion. The mean lowest detectable doses of inhibin capable of decreasing LH-RH-induced FSH and LH secretion, calculated at $95 \%$ confidence limit of gonadotrophin secretion in the absence of inhibin, were $86 \pm 25 \mu \mathrm{g}$ and $337 \pm 59 \mu \mathrm{g}$ respectively. In basal conditions, the FSH inhibition curves were less sensitive (lowest detectable dose of inhibin $315 \pm 62 \mu \mathrm{g}$ ) and less precise (index of precision, $\lambda$, range $0.15-0.41$ ) than when the secretion was stimulated by LH-RH addition to cultures $(86 \pm 25 \mu \mathrm{g}$ inhibin and $\lambda 0 \cdot 06-0 \cdot 19)$. The inhibition of LH-RH-induced FSH secretion by pituitary cells was therefore considered to be the better method for determining inhibin activity and was used for comparison to the standard.

\section{Influence of culture conditions on inhibin production by granulosa cells}

Granulosa cells cultured in medium devoid of calf serum failed to secrete inhibin. Only medium from granulosa cells cultured in medium with $10 \%$ calf serum selectively inhibited basal FSH production (as demonstrated in Text-fig. 1) and preferentially inhibited LH-RH stimulated FSH production (Table 1) by pituitary cells. Granulosa cells cultured in medium with $10 \%$ calf serum underwent morphological and functional changes indicative of luteinization, i.e. cellular hyperplasia and hypertrophy and increased progesterone production (Table 1). Addition of bovine gonadotrophins to the culture medium mimicked the effect of serum in stimulating granulosa cell progesterone production but not the effect of serum in stimulating inhibin production (Table 1).

\section{Relative production of inhibin by granulosa and luteal cells}

To test the possibility that inhibin production by granulosa cells might be related to their luteinization, inhibin production by luteinizing granulosa cells and luteal cells was compared. Results in Text-fig. 2 show that as granulosa cell progesterone production increased, inhibin production decreased. Although dispersed luteal cells do not survive well in culture (Henderson \& Moon, 1979), as indicated by a steady decline in their production of progesterone, substantial amounts of progesterone were produced during the 2 days of culture, indicative of some functional viability. No detectable amounts of inhibin, however, were produced by the luteal cells. 
FSH
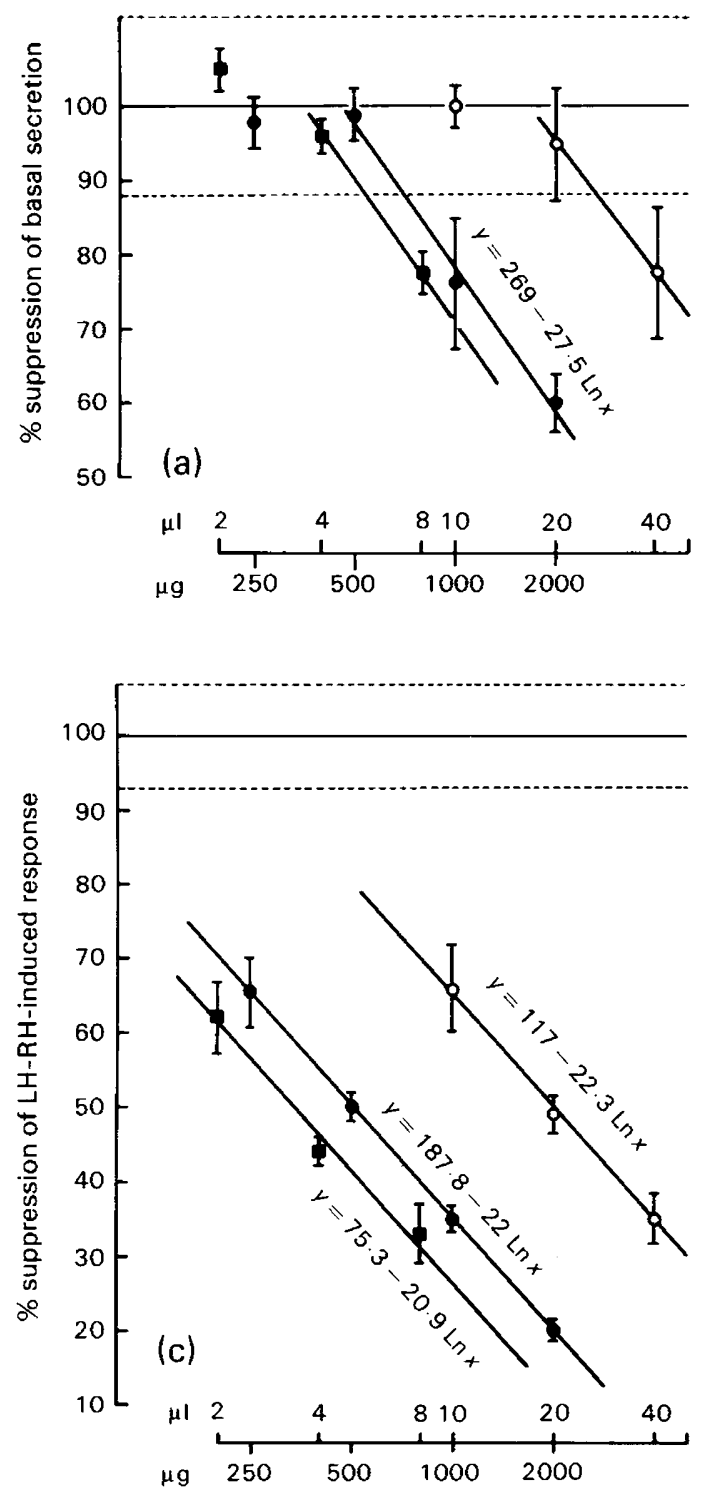

$\mathrm{LH}$
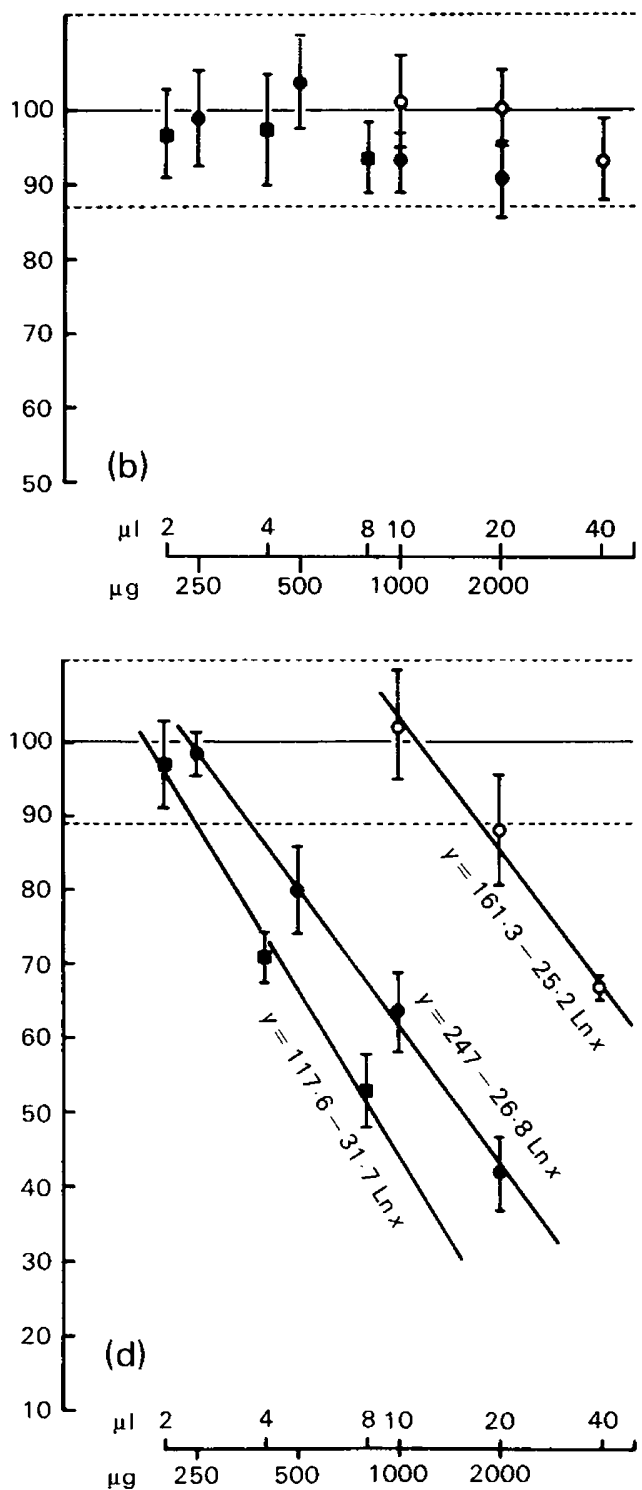

Text-fig. 1. Effect of progressive amount of the inhibin standard (O) and volumes of bovine follicular fluid ( $\square$ ) and granulosa cell culture medium (O) on basal FSH (a) and LH (b) secretion and on LH-RH-induced release of FSH (c) and LH (d). FSH and LH concentrations are expressed as \% of control (100\%, no added inhibin preparations). Each is the mean curve of 17 individual curves. Each point represents the mean \pm s.d. Broken lines represent 2 s.d. from the $100 \%$ control value.

\section{Relationship between progesterone and inhibin production by granulosa cells}

The analysis of several granulosa cell culture experiments revealed an inverse relationship between progesterone and inhibin production (Text-fig. 3). 
Table 1. Relative efficiency of calf serum and bovine gonadotrophins in stimulating inhibin and progesterone production by bovine granulosa cells cultured for $24 \mathrm{~h}$

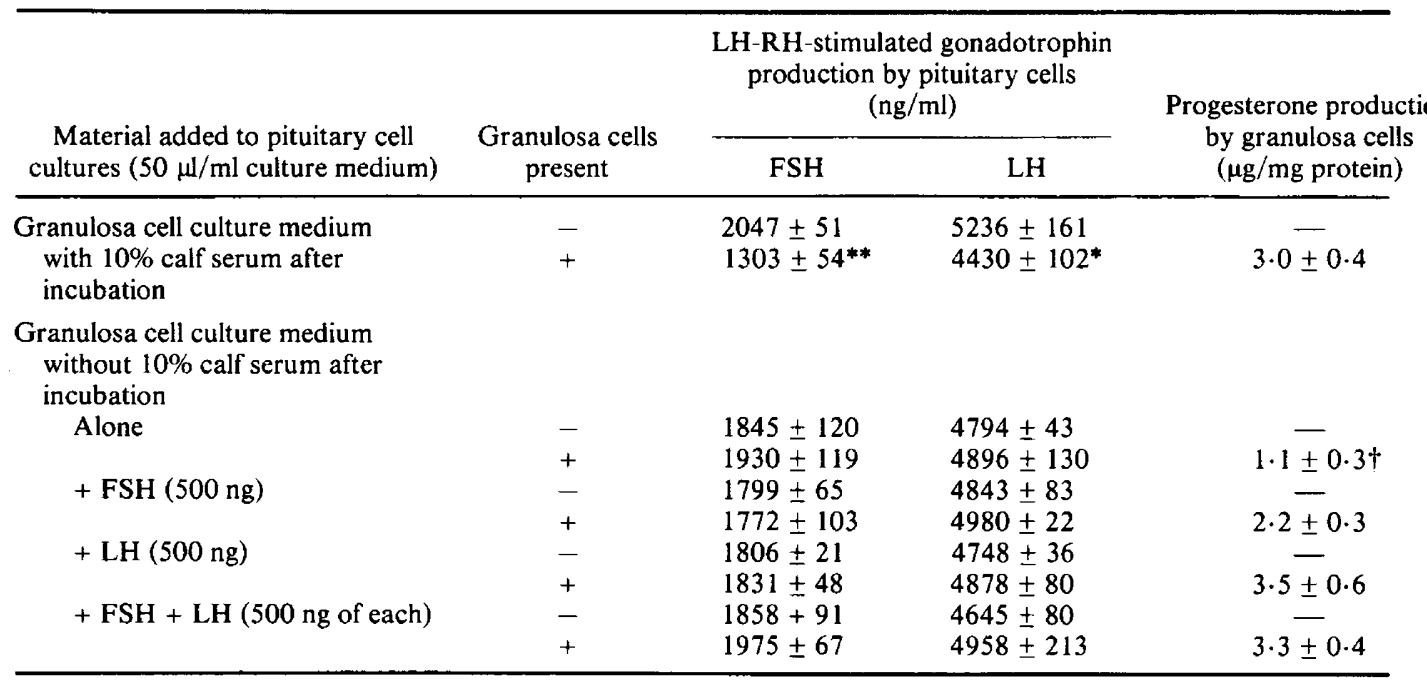

Values are mean \pm s.e.m. for 5 replicate cultures.

Values significantly different from effect of culture medium with $10 \%$ calf serum but no granulosa cells; ${ }^{*} P<0 \cdot 01$, ${ }^{* *} P<0.005$.

$\dagger$ Significantly different from other values in same column: $P<0.05$.
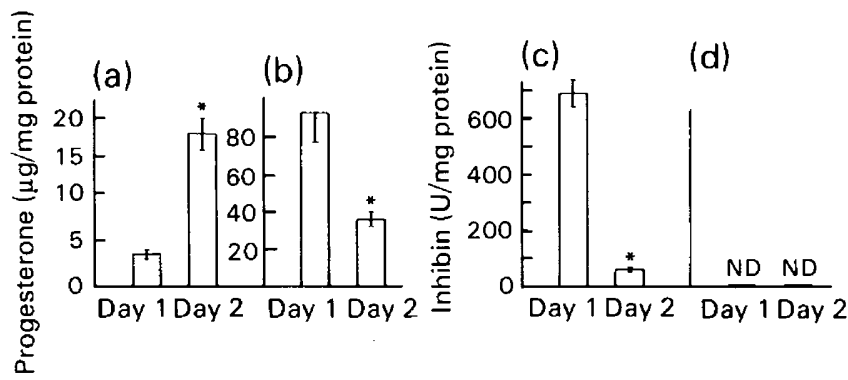

Text-fig. 2. Progesterone (a, b) and inhibin (c, d) production by $10^{6}$ granulosa $(\mathrm{a}, \mathrm{c})$ and $10^{6}$ luteal $(b, d)$ cells on Days 1 and 2 of culture. Values are means \pm s.d. for 6 replicate cultures; ND $=$ not detectable. ${ }^{*}$ Significantly different from Day 1 value $(P<0 \cdot 01)$.

Effect of exogenous steroids on inhibin production and steroidogenesis by granulosa and luteal cells

The results in Table 2 demonstrate that androstenedione at $5 \mu \mathrm{g} / \mathrm{ml}$ and testosterone at 1 and $5 \mu \mathrm{g} / \mathrm{ml}$ significantly stimulated granulosa cell inhibin production. In contrast, progesterone at 1 and $5 \mu \mathrm{g} / \mathrm{ml}$ significantly inhibited inhibin production. Oestrogens had no significant effect $(P>0.05)$ on inhibin production. All the granulosa cell cultures produced significantly less inhibin during the 2 nd day of culture than during the 1 st day $(P<0.01)$. Progesterone production by granulosa cells was significantly inhibited by oestrogens and androgens during the 2 nd day, but not during the 1 st day of culture. Oestradiol- $17 \beta$ production by the granulosa cells increased during the 1st day of culture in response to the exogenous androgens and then decreased 5-10-fold during the 2nd day of culture, relative to Day 1.

The effects of the same doses of an aromatizable and non-aromatizable androgen (testosterone and 5a-dihydrotestosterone (DHT) respectively) on inhibin production by 


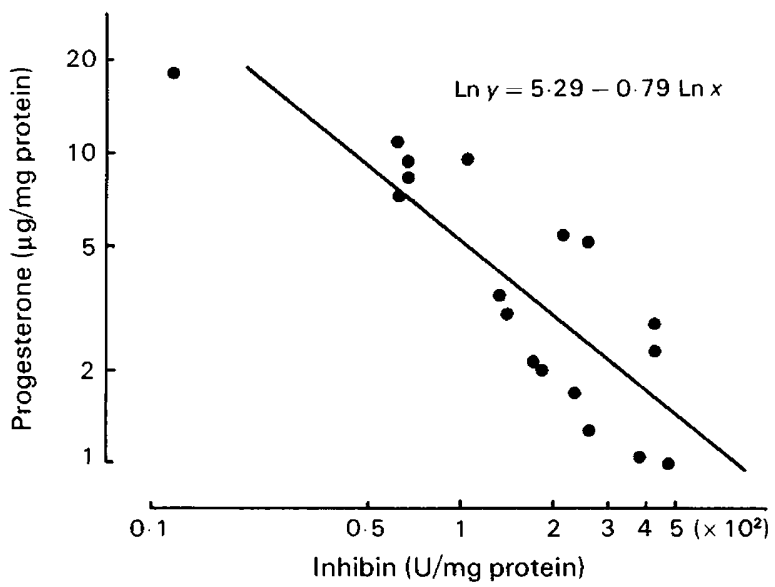

Text-fig. 3. Relationship between progesterone and inhibin production by bovine granulosa cells in culture. The coefficient of linear correlation $(r)=0.83$ with $P<0.001(n=18)$.

Table 2. Effect of steroids on inhibin production and steroidogenesis by bovine granulosa cells in culture

\begin{tabular}{|c|c|c|c|c|c|c|}
\hline \multirow{3}{*}{$\begin{array}{l}\text { Additions to } \\
\text { culture medium } \\
\text { (dose/ml) }\end{array}$} & \multirow{2}{*}{\multicolumn{2}{|c|}{$\begin{array}{l}\text { Inhibin production } \\
\text { (U/mg protein) }\end{array}$}} & \multicolumn{4}{|c|}{ Steroid production ( $\mu \mathrm{g} / \mathrm{mg}$ protein) } \\
\hline & & & \multicolumn{2}{|c|}{ Progesterone } & \multicolumn{2}{|c|}{ Oestradiol-17 $\beta$} \\
\hline & Day 1 & Day 2 & Day 1 & Day 2 & Day 1 & Day 2 \\
\hline None & $375 \pm 16$ & $205 \pm 7$ & $1.0 \pm 0.08$ & $5.5 \pm 0.28$ & $0.3 \pm 0.08$ & $0.3 \pm 0.09$ \\
\hline $\begin{array}{c}\text { Oestrone } \\
1 \mu \mathrm{g} \\
5 \mu \mathrm{g}\end{array}$ & $\begin{array}{l}386 \pm 23 \\
391 \pm 16\end{array}$ & $\begin{array}{l}194 \pm 7 \\
222 \pm 10\end{array}$ & $\begin{array}{l}0.9 \pm 0.02 \\
0.8 \pm 0.06\end{array}$ & $\begin{array}{l}2.1 \pm 0.07^{d} \\
1.1 \pm 0.08^{d}\end{array}$ & $\begin{array}{c}33 \pm 3^{\mathrm{d}} \\
166 \pm 12^{\mathrm{d}}\end{array}$ & $\begin{aligned} 79 & \pm 8^{\mathrm{d}} \\
152 & \pm 10^{\mathrm{d}}\end{aligned}$ \\
\hline $\begin{array}{l}\text { Oestradiol-17 } \\
\quad 1 \mu \mathrm{g} \\
5 \mu \mathrm{g}\end{array}$ & $\begin{array}{l}386 \pm 9 \\
360 \pm 13\end{array}$ & $\begin{array}{l}204 \pm 11 \\
218 \pm 8\end{array}$ & $\begin{array}{l}0.9 \pm 0.04 \\
0.8 \pm 0.07\end{array}$ & $\begin{array}{l}2.2 \pm 0.04^{d} \\
1.1 \pm 0.09^{d}\end{array}$ & - & - \\
\hline $\begin{array}{l}\text { Androstenedione } \\
1 \mu \mathrm{g} \\
5 \mu \mathrm{g}\end{array}$ & $\begin{array}{l}437 \pm 24 \\
477 \pm 13^{\mathrm{c}}\end{array}$ & $\begin{array}{l}211 \pm 5 \\
267 \pm 17^{\mathrm{c}}\end{array}$ & $\begin{array}{l}1.1 \pm 0.07 \\
1.0 \pm 0.05\end{array}$ & $\begin{array}{l}3.4 \pm 0.17^{\mathrm{d}} \\
1.3 \pm 0.11^{\mathrm{d}}\end{array}$ & $\begin{array}{l}3 \cdot 0 \pm 0.3^{d} \\
5 \cdot 5 \pm 0.8^{d}\end{array}$ & $\begin{array}{l}0.3 \pm 0.01 \\
1.3 \pm 0.3^{c}\end{array}$ \\
\hline $\begin{array}{c}\text { Testosterone } \\
1 \mu \mathrm{g} \\
5 \mu \mathrm{g}\end{array}$ & $\begin{array}{l}597 \pm 22^{\mathrm{d}} \\
681 \pm 37^{\mathrm{d}}\end{array}$ & $\begin{array}{l}249 \pm 7^{\mathrm{c}} \\
277 \pm 11^{\mathrm{d}}\end{array}$ & $\begin{array}{l}1.2 \pm 0.09 \\
1.0 \pm 0.04\end{array}$ & $\begin{array}{l}3.5 \pm 0.42^{\mathrm{c}} \\
2.3 \pm 0.34^{\mathrm{d}}\end{array}$ & $\begin{array}{l}4.9 \pm 0.4^{\mathrm{d}} \\
6.4 \pm 0.3^{\mathrm{d}}\end{array}$ & $\begin{array}{l}0.6 \pm 0.06^{a} \\
0.5 \pm 0.04\end{array}$ \\
\hline $\begin{array}{c}\text { Progesterone } \\
1 \mu \mathrm{g} \\
5 \mu \mathrm{g}\end{array}$ & $\begin{array}{l}170 \pm 9^{d} \\
284 \pm 33^{a}\end{array}$ & $\begin{array}{l}\text { ND } \\
\text { ND }\end{array}$ & - & - & $\begin{array}{l}\text { ND } \\
\text { ND }\end{array}$ & $\begin{array}{l}\text { ND } \\
\text { ND }\end{array}$ \\
\hline
\end{tabular}

Values are mean \pm s.e.m. for 5 replicate cultures. ND, not detectable.

Values significantly different from those for cultures with no additions: ${ }^{a} P<0.05 ;{ }^{b} P<0.02 ;{ }^{c} P<0.01 ;{ }^{d} P<0.001$.

granulosa cells in a separate experiment is shown in Table 3. Both androgens caused a significant (except for $1 \mu \mathrm{g} \mathrm{DHT} / \mathrm{ml}$ during the 2 nd day of culture) and dose-related increase in inhibin production during both days of culture. Consistent with the results in Table 2, both androgens significantly inhibited progesterone production. Oestradiol-17 $\beta$ production was again stimulated by testosterone with less oestradiol-17 $\beta$ being produced during the 2 nd than during the 1 st day of culture. A small, but significant, amount of oestradiol-17 $\beta$ was also produced in response to exogenous DHT. This may be the result of slight $(<1 \%)$ testosterone contamination of the commercial preparation of DHT which was not repurified before use. 
Table 3. Effect of androgens on inhibin and steroidogenesis by bovine granulosa cells in culture

\begin{tabular}{|c|c|c|c|c|c|c|}
\hline \multirow{3}{*}{$\begin{array}{l}\text { Addition to } \\
\text { culture medium } \\
\text { (dose } / \mathrm{ml} \text { ) }\end{array}$} & \multirow{2}{*}{\multicolumn{2}{|c|}{$\begin{array}{l}\text { Inhibin production } \\
\text { (U/mg protein) }\end{array}$}} & \multicolumn{4}{|c|}{ Steroid production $(\mu \mathrm{g} / \mathrm{mg}$ protein) } \\
\hline & & & \multicolumn{2}{|c|}{ Progesterone } & \multicolumn{2}{|c|}{ Oestradiol-17 $\beta$} \\
\hline & Day 1 & Day 2 & Day 1 & Day 2 & Day 1 & Day 2 \\
\hline None & $427 \pm 19$ & $260 \pm 10$ & $2.9 \pm 0.3$ & $5.4 \pm 0.3$ & ND & ND \\
\hline $\begin{array}{l}\text { Testosterone } \\
1 \mu \mathrm{g} \\
5 \mu \mathrm{g}\end{array}$ & $\begin{array}{l}1436 \pm 51^{\mathrm{d}} \\
2205 \pm 68^{\mathrm{d} *}\end{array}$ & $\begin{array}{l}435 \pm 21^{\mathrm{d}} \\
742 \pm 28^{\mathrm{d} *}\end{array}$ & $\begin{array}{l}2.4 \pm 0.2 \\
1.6 \pm 0.4^{\mathrm{a}}\end{array}$ & $\begin{array}{l}3.3 \pm 0.3^{c} \\
2.4 \pm 0.4^{d}\end{array}$ & $\begin{array}{l}23 \pm 3 \\
21 \pm 3\end{array}$ & $\begin{array}{l}2 \cdot 0 \pm 0.3 \\
2 \cdot 0 \pm 0.1\end{array}$ \\
\hline $\begin{array}{l}\text { 5a-Dihydrotestoste } \\
1 \mu \mathrm{g} \\
5 \mu \mathrm{g}\end{array}$ & $\begin{array}{l}1362 \pm 41^{d} \\
2848 \pm 89^{d *}\end{array}$ & $\begin{array}{l}285 \pm 8 \\
478 \pm 15^{\mathrm{d} *}\end{array}$ & $\begin{array}{l}2.2 \pm 0.4 \\
1.7 \pm 0.2^{\mathrm{b}}\end{array}$ & $\begin{array}{l}3 \cdot 5 \pm 0 \cdot 7^{\mathrm{a}} \\
3 \cdot 0 \pm 0 \cdot 4^{\mathrm{c}}\end{array}$ & $\begin{array}{l}0.3 \pm 0.06 \\
0.2 \pm 0.04\end{array}$ & $\begin{array}{l}0.1 \pm 0.01 \\
0.1 \pm 0.03\end{array}$ \\
\hline
\end{tabular}

Values are mean \pm s.e.m. for 6 replicate cultures. ND, not detectable.

Values significantly different from those for cultures with no additions: ${ }^{\mathrm{a} P}<0.05 ;{ }^{\mathrm{b}} P<0.02 ;{ }^{\mathrm{c}} P<0.01 ;{ }^{\mathrm{d}} P<0.001$.

* Significantly different from the lower concentration value: $P<0.001$.

Table 4. Effect of testosterone on inhibin production and steroidogenesis by bovine granulosa and luteal cells in culture

\begin{tabular}{|c|c|c|c|c|c|c|}
\hline \multirow{3}{*}{$\begin{array}{l}\text { Addition to } \\
\text { culture media }\end{array}$} & \multirow{2}{*}{\multicolumn{2}{|c|}{$\begin{array}{l}\text { Inhibin production } \\
\text { (U/mg protein) }\end{array}$}} & \multicolumn{4}{|c|}{ Steroid production ( $\mu \mathrm{g} / \mathrm{mg}$ protein) } \\
\hline & & & \multicolumn{2}{|c|}{ Progesterone } & \multicolumn{2}{|c|}{ Oestradiol-17 $\beta$} \\
\hline & Day 1 & Day 2 & Day 1 & Day 2 & Day 1 & Day 2 \\
\hline \multicolumn{7}{|l|}{ Granulosa cells } \\
\hline None & $470 \pm 21$ & $293 \pm 11$ & $0.9 \pm 0.1$ & $2 \cdot 1 \pm 0 \cdot 1$ & ND & ND \\
\hline $\begin{array}{c}\text { Testosterone, } \\
1 \mu \mathrm{g} / \mathrm{ml}\end{array}$ & $850 \pm 36^{*}$ & $483 \pm 13^{*}$ & $0.7 \pm 0.2$ & $0.9 \pm 0.3^{*}$ & $15 \pm 2$ & $1.0 \pm 0.3$ \\
\hline \multicolumn{7}{|l|}{ Luteal cells } \\
\hline $\begin{array}{l}\text { None } \\
\text { Testosterone }\end{array}$ & ND & ND & $160 \pm 29$ & $17 \pm 2$ & ND & ND \\
\hline $1 \mu \mathrm{g} / \mathrm{ml}$ & ND & ND & $115 \pm 15$ & $20 \pm 1$ & ND & ND \\
\hline
\end{tabular}

Values are mean \pm s.e.m. for 6 replicate cultures. ND, not detectable.

* Significantly different from value for culture with no addition: $P<0.001$.

While testosterone stimulated inhibin production by granulosa cells, it had no effect on luteal cells which failed to produce any detectable amounts of inhibin in the presence or absence of testosterone (Table 4).

Although the granulosa cell culture media were treated with dextran-charcoal before being assayed for inhibin, it could be argued that the effects of the steroids on granulosa cell inhibin production might be artefacts caused by steroids, still present following dextran-charcoal treatment of the media, modifying pituitary FSH production. Addition to pituitary cell cultures of equivalent volumes $(50 \mu \mathrm{l})$ of dextran-charcoal treated culture medium containing added steroids but not exposed to granulosa cells revealed, however, that only at the higher concentration tested $(5 \mu \mathrm{g} / \mathrm{ml})$ did any of the steroids themselves significantly modify FSH production. Testosterone and progesterone significantly increased $(P<0.01) \mathrm{FSH}$ production (mean \pm s.e.m. for $n=5$ ) from $1597 \pm 38$ to $1790 \pm 30$ and $1839 \pm 33 \mathrm{ng} / \mathrm{ml}$ respectively, and oestrone significantly reduced $(P<0.05) \mathrm{FSH}$ production from $1597 \pm 38$ to $1459 \pm 41 \mathrm{ng} / \mathrm{ml}$. The other steroids had no effect on FSH production. 


\section{Inhibin and steroid concentrations in follicular fluid}

Inhibin and testosterone concentrations in follicular fluid fell significantly $(P<0.01)$ as follicle size increased while the concentration of oestradiol- $17 \beta$ rose significantly $(P<0.01)$ (Table 5). There was no significant relationship between follicle size and progesterone concentrations $(P>0.05)$.

Table 5. Relationship between follicle size and the inhibin and steroid concentrations in bovine follicular fluid

\begin{tabular}{lrcc}
\hline & \multicolumn{3}{c}{$\begin{array}{c}\text { Follicle size } \\
\text { (ml antral fluid/follicle) }\end{array}$} \\
\cline { 2 - 4 } & \multicolumn{1}{c}{$<0.3$} & $\geqslant 0 \cdot 3-<0 \cdot 8$ & $\geqslant 0 \cdot 8$ \\
& \multicolumn{1}{c}{$(17)^{*}$} & $(25)^{*}$ & $(21)^{*}$ \\
\hline Inhibin $(\mathrm{U} / \mathrm{ml})$ & $308 \pm 32$ & $181 \pm 17$ & $155 \pm 15$ \\
Oestradiol-17 $\beta(\mathrm{ng} / \mathrm{ml})$ & $9 \pm 2$ & $133 \pm 39$ & $181 \pm 45$ \\
Testosterone $(\mathrm{ng} / \mathrm{ml})$ & $43 \pm 5$ & $29 \pm 10$ & $16 \pm 5$ \\
Progesterone $(\mathrm{ng} / \mathrm{ml})$ & $44 \pm 4$ & $55 \pm 11$ & $63 \pm 14$ \\
\hline
\end{tabular}

* Minimum number of determinations in each group. Values are mean \pm s.e.m.

There was a significant relationship between follicle size and concentrations of inhibin, oestradiol $17 \beta$ and testosterone $(P<0.01$; Kruskal-Wallis test).

\section{Discussion}

Dispersed pituitary cell culture has already been used as a method for assaying inhibin (de Jong et al., 1978; Eddie et al., 1979; Franchimont et al., 1979a, b; Scott, Burger \& Quigg, 1980). In our experimental conditions, inhibin preparations extracted from rete testis (Franchimont et al., 1979a), from testicular lymph and produced by granulosa cells (Text-fig. 1) specifically decrease basal FSH secretion, and they preferentially inhibit LH-RH-induced FSH secretion. Low doses decrease only LH-RH-induced FSH release whereas higher doses reduce both FSH and $\mathrm{LH}$ release under the influence of LH-RH. This preferential effect is due to the fact that inhibin specifically reduces FSH synthesis, but reduces FSH and LH release, although LH release is reduced to a lesser extent (Franchimont et al., 1979b). As inhibition of LH-RH-induced FSH secretion is more precise and sensitive than the specific inhibition of basal FSH secretion, this response was chosen as the end point of the inhibin bioassay (Text-fig. 1). The criteria for the quality of a parallel line assay are fulfilled (Borth, 1976). The specificity of the inhibin assay was ascertained by the absence of an effect on prolactin and thyrotrophin secretion in basal and LH-RH-stimulated conditions, by the absence of inhibition of basal LH secretion and by a more marked inhibition of LH-RH-induced FSH secretion than that of LH-RH-stimulated LH release (Franchimont et al., 1979a).

Granulosa cells cultured in medium devoid of calf serum failed to produce inhibin. The nature of the factor(s) present in serum and responsible for stimulating granulosa cell inhibin production is unknown but is unlikely to be endogenous gonadotrophins. Bovine LH and/or FSH added to medium devoid of serum, although mimicking the effect of serum in stimulating granulosa cell progesterone production, failed to stimulate inhibin production. No effect on inhibin production by rat granulosa cells cultured in medium containing $10 \%$ calf serum was observed when PMSG, a predominantly FSH-like gonadotrophin, was added at increasing doses $(0.02$ to 1 i.u.) to the culture medium (F. Crooze \& P. Franchimont, unpublished observations).

Luteinization of granulosa cells, as indicated in culture by cellular hyperplasia and 
hypertrophy and increased progesterone production, was accompanied by a reduction in inhibin production. There was an inverse relationship between granulosa cell progesterone and inhibin production. This is unlikely to be an artefact of the culture system because bovine luteal tissue, of which luteinized granulosa cells constitute a major portion, failed to produce any detectable amounts of inhibin in vitro. Thus, luteinization of granulosa cells and corpus luteum formation in vivo may be accompanied by a reduction in ovarian inhibin production. The finding that exogenous progesterone inhibited inhibin production by granulosa cells suggests that the reduction in inhibin production accompanying granulosa cell luteinization may be due to the increased progesterone produced having a negative feedback effect on cellular inhibin production.

Whatever the dose and the day of culture, exogenous oestrogens failed to modify granulosa cell inhibin production. They did, however, significantly reduce progesterone production by the cells as previously demonstrated (Fortune \& Hansel, 1979). A stimulatory effect of androstenedione, testosterone and $5 \alpha$-dihydrotestosterone on inhibin production by granulosa cells was evident and was dose-dependent for testosterone and dihydrotestosterone. This stimulatory effect was less marked during the 2 nd day of culture and may be due to an inhibitory action of the increased progesterone produced by the granulosa cells over-riding the stimulatory effect of the androgens. The extent by which inhibin production was stimulated by testosterone $(1 \mu \mathrm{g} / \mathrm{ml})$ during the 1 st day of culture varied between experiments from 1.6 - to 3.4 -fold (Tables 2,3 and 4 ). This probably reflects different sensitivities to testosterone of the pools of granulosa cells used in each study. Further studies to compare the responsiveness to androgens of granulosa cells from individual follicles therefore seem worthwhile. The stimulatory effect of androstenedione and testosterone on inhibin production was associated with their aromatization to oestradiol-17 $\beta$ during the 1 st day of culture. During the 2 nd day of culture, luteinization of the granulosa cells was accompanied by a reduction in their capacity to aromatize androgens (Henderson \& Moon, 1979). The stimulatory effect of the androgens on inhibin production is a direct one, however, and not secondary to their capacity to be aromatized to oestrogens. Exogenous oestrogens failed to modify granulosa cell inhibin production, and 5a-dihydrotestosterone, essentially a non-aromatizable androgen, stimulated inhibin production. Although stimulating inhibin production by granulosa cells, testosterone did not induce inhibin production by luteal cells. In addition to their effect on inhibin production, the androgens also inhibited progesterone production by granulosa cells.

Measurement of steroids and inhibin concentrations in bovine follicular fluid indicated that as follicle size increased there was a significant fall in fluid concentrations of testosterone and inhibin. The fall in testosterone may be due to its increased aromatization by follicular granulosa cells because the follicular fluid concentrations of oestradiol- $17 \beta$ rose as those of the testosterone fell. Taking together the observation that follicular fluid concentrations of testosterone and inhibin both fell as follicle size increased, and the finding that androgens stimulated granulosa cell inhibin production in vitro, androgens may modify, at least in part, granulosa cell inhibin production in vivo. There was no relationship between follicle size and follicular fluid concentrations of progesterone. The inhibitory effect of progesterone on granulosa cell inhibin production may therefore be more important in regulating ovarian inhibin production during the period of granulosa cell luteinization and corpus luteum formation, when progesterone levels become elevated.

Androgens acting locally within the ovary may be involved in the process of follicular atresia (Louvet, Harman, Schreiber \& Ross, 1975; Hillier \& Ross, 1979). Androgens may also promote follicular atresia through stimulating granulosa cell inhibin production which would act to inhibit pituitary FSH production. FSH stimulates ovarian androgen aromatization (Armstrong \& Papkoff, 1976) and so a decrease in FSH levels would produce an accumulation of follicular androgen from LH action on the theca (Leung \& Armstrong, 1979). A closed cycle would thus be formed with the excess androgen driving the follicle further into atresia. 
Materials for the RIA of rat gonadotrophins were provided by the NIAMDD rat pituitary hormone distribution programme. Antisera to steroids were provided by the M.R.C. Reproductive Biology Unit, Edinburgh, Scotland. This work was supported by grant No. 3.4501.80 from the Belgium Foundation for Medical Research (F.R.S.M.), by grant No. 74.039 of the World Health Organisation and by the Australian Research Grants Committee. K.M.H. is presently in receipt of an Australian Queen Elizabeth II Research Fellowship.

\section{References}

Armstrong, D.T. \& Papkoff, H. (1976) Stimulation of aromatization of exogenous and endogenous androgens in ovaries of hypophysectomized rats in vivo by follicle stimulating hormone. Endocrinology 99, 1144-1151.

Borth, R. (1976) Statistics of parallel-line assay. In Methods of Hormone Analysis, pp. 500-513. Eds H. Breuer, D. Hamel \& H. L. Kruskemper. Georg Thieme Verlag, Stuttgart.

Channing, C.P., Anderson, L. \& Hodgen, G.D. (1980) A search for inhibin activity in monkey ovarian vein blood and follicular fluid. Proc. 6th Int. Congr. Endocrinology, Melbourne, Abstr. 178.

Chappel, S.C., Holt, J.A. \& Spies, H.G. (1980) Inhibin: differences in bioactivity within human follicular fluid in the follicular and luteal stages of the menstrual cycle. Proc. Soc. exp. Biol. Med. 163, 310-314.

Corker, C. \& Davidson, D. (1978) A radioimmunoassay for testosterone in various biological fluids without chromatography. J. Steroid Biochem. 9, 373-374.

de Jong, F.H., Welschen, R., Hermans, W. P., Smith, S.D. \& van der Molen, H.J. (1978) Effects of testicular and ovarian inhibin-like activity using in vitro and in vivo systems. Int. J. Androl, Suppl. 2, 125-138.

de Paolo, L.V., Shander, D., Wise, P.M., Barraclough, C.A. \& Channing, C.P. (1979a) Identification of inhibin-like activity in ovarian venous plasma of rats during the estrous cycle. Endocrinology 105, 647654.

de Paolo, L.V., Wise, P.M., Anderson, L.D., Barraclough, C.A. \& Channing C.P. (1979b) Suppression of the pituitary FSH secretion during proestrous and estrus in rats by porcine follicular fluid: possible site of action. Endocrinology 104, 402-408.

Dulbecco, R. \& Freeman, G. (1959) Plaque production by the polyoma virus. Virology 8, 396-397.

Eagle, H. (1959) Amino acid metabolism in mammalian cell cultures. Science, N.Y. 130, 432-437.

Eddie, L.W., Baker, H.W.G., Higginson, R.E. \& Hudson, B. (1979) A bioassay for inhibin using pituitary cell cultures. J. Endocr. 81, 49-60.

Erickson, G.F. \& Hsueh, A.J.W. (1978) Secretion of inhibin by rat granulosa cells in vitro. Endocrinology 103, 1960-1963.

Finney, D.J. (1964) Statistical Methods in Biological Assay, 2nd edn, pp. 99-136. Griffin \& Co. Ltd, London.

Fortune, J.E. \& Hansel, W. (1979) The effects of $17 \beta$-estradiol on progesterone secretion by bovine theca and granulosa cells. Endocrinology 104, 1834-1838.

Franchimont, P., Demoulin, A., Verstraelen-Proyard, J., Haxee-Hagelstein, M.T. \& Tunbridge, W.M.G. (1979a) Identification in human seminal fluid of an inhibin-like factor which selectively regulates FSH secretion. J. Reprod. Fert., Suppl. 26, 123-133.

Franchimont, P., Verstraelen-Proyard, J., HazeeHagelstein, M.T., Renard, Ch., Demoulin, A., Bourguignon, J.P. \& Hustin, J. (1979b) Inhibin: from concept to reality. Vitams Horm. 37, 243-302.

Henderson, K.M. \& Moon, Y.S. (1979) Luteinization of bovine granulosa cells and corpus luteum formation associated with loss of androgen aromatizing ability. J. Reprod. Fert. 56, 89-97.

Hillier, S.G. \& Ross, G.T. (1979) Effects of exogenous testosterone on ovarian weight, follicular morphology and intraovarian progesterone concentration in estrogen-primed hypophysectomized immature female rats. Biol. Reprod. 20, 261-268.

Hopkins, C.R. \& Farquhar, M.G. (1973) Hormone secretion by cells dissociated from rat anterior pituitaries. J. Cell Biol. 59, 276-303.

Leung, P.C.K. \& Armstrong, D.T. (1979) A mechanism for the intraovarian action of estrogen on androgen production. Biol. Reprod. 21, 1035-1042.

Louvet, J.P., Harman, S.M., Schreiber, J.R. \& Ross, G.T. (1975) Evidence for a role of androgens in follicular maturation. Endocrinology 97, 366-372.

Lowry, O.H., Rosebrough, N.J., Farr, A.L. \& Randall, R.S. (1951) Protein measurement with the Folin phenol reagent. J. biol. Chem. 193, 265-275.

Miller, K.F., Wesson, J.A. \& Ginther, O.J. (1979) Changes in concentrations of circulating gonadotrophins following administration of equine follicular fluid to ovariectomized mares. Biol. Reprod. 21, 867-872.

Neal, P., Baker, T.G., MeNatty, K.P. \& Scaramuzzi, R.J. (1975) Influence of progesterone and human chorionic gonadotrophin on progesterone concentrations and oocyte maturation in mouse ovarian follicles maintained in organ culture. $J$. Endocr. 65, 19-25.

Patterson, M.K. (1979) Measurement of growth and viability of cells in culture. In Methods in Enzymology, vol. 58, pp. 141-152. Eds W.B. Jakoby \& I.H. Pastan. Academic Press, New York.

Schander, D., Anderson, L.D., Barraclough, C.A. \& Channing, C.P. (1980) Interactions of porcine follicular fluid with ovarian steroids and luteinizing hormone releasing hormone on the secretion of Downloaded from Bioscientifica.com at 04/26/2023 07:13:23AM via free access 
luteinizing hormone and follicle stimulating hormone by cultured pituitary cells. Endocrinology 106, 237-242.

Scott, R.S., Burger, H.G. \& Quigg, H. (1980) A simple and rapid in vitro bioassay for inhibin. Endocrinology 107, 1536-1542.

Van Look, P.F.A., Hunter, W.M., Corker, C.S. \& Baird, D.T. (1977) Failure of positive feedback in normal men and subjects with testicular feminization. Clin. Endocr. 7, 353-366.

Welschen, R., Hermans, W.P., Dullart, J. \& de Jong, F.H. (1977) Effects of an inhibin-like factor present in bovine and porcine follicular fluid on gonadotrophin levels in ovariectomized rats. J. Reprod. Fert. 50, 129-131.

Received 16 January 1981 